\title{
KOMÁROM DUNA-PARTJÁNAK VÁROSTÖRTÉNETE A KEZDETEKTÖL 1945-IG
}

\author{
TAMÁSKA MÁTÉ \\ PhD, OTKA kutatásvezető. ELTE Társadalomtudományi Kar, Város és Regionális Kutatások Központja. \\ 1117 Budapest, Pázmány Péter sétány 1/a. Meghívott kutató, oktató, Széchenyi István Egyetem, \\ Építészettörténeti és Városépítési Tanszék. E-mail: tamaskamate@gmail.com
}

\begin{abstract}
A tanulmány célja, hogy Komárom városfejlődésén keresztül bemutassa a város és a Duna-part, illetve a Duna két partjának történeti kapcsolatrendszerét. Komárom szerkezetének sajátossága kiemelt hadászati jelentősége, amelyet elsőként, mint török kori végvár élt meg. Ebben az időben a Duna túlpartján feltehetően már korábban létező településkezdeményezések elpusztultak. A 18. században, mint kereskedőváros, jelentős fejlődést tudhat magáénak, ám gazdasági jelentősége ellenére városképe egyszerủ maradt. A 19. századtól ismét erőd jellege válik a meghatározóvá, a Duna-part stratégiai hídfőit elfoglalják a katonai létesítmények. Csupán a 20. század első évtizedeiben kerül sor a déli és az északi part egybekapcsolására, ami nemcsak a hidat jelenti, hanem az északi hídfő körül akkoriban kiépülő reprezentatív teresedést és parkot is. A két világháború között a frissen egyesített várost határ szeli ketté. A közös városi zónát, így mindenekelőtt a hídfők környékét, illetve általában a Duna-partokat elfoglalják az ipari létesítmények. A két város közé ékelődő ipari zóna azóta is meghatározó szerkezeti eleme a városnak.
\end{abstract}

Kulcsszavak: várostörténet, városbővítés, dunai városképek, megosztott határváros, várostervezés, Wälder Gyula, Bierbauer Virgil

„Feltehetőleg kevés olyan város van még a Duna mellett, amelynek a Dunával való kapcsolata ilyen szerencsétlenül alakult volna"1 - olvashatjuk egy, a mai Komárom földrajzi adottságait és fejlődési potenciáit tárgyaló tudományos munkában. Nem éppen bíztató kijelentés, hiszen a történeti város a folyónak köszönheti létét. A Duna városfejlesztő hatása mutatkozik meg egykori kereskedelmi életében, erődítés jellegében, átkelőhely szerepében éppúgy, mint megyeszékhelyi funkciójában, de a városegyesítés és városkettéosztás századfordulótól a második világháborúig ívelő szakasza is a Duna-partok rendezésének történetét tárja elénk. Budapest példája mutatja, hogy a folyón átívelő egységes városkép kimagasló esztétikai élményt nyújthat. S ha Komáromban nincs is Várhegy, az Erzsébet-sziget, a GyőriDuna és a Vág-Duna torkolata páratlanul gazdag táji keretet nyújt. Komárom mégsem lett kis Budapest. Jelen tanulmány ennek okait igyekszik feltárni, visszanyúlva a történeti gyökerekig, de leginkább a 20. század első felére koncentrálva. Szük fél évszázad alatt Ó-Komárom egyesült Új-Szőnnyel (1900), majd országhatár került

${ }^{1}$ Sikos T. - Tiner 2007. 57. 
közéjük (1920-1938), végül a bécsi döntés után néhány évig ismét egy városi teret alkot a két part.

Az itt ismertetett esettanulmány egy átfogóbb, a dunai városi táj mintázatait, azon belül is a megosztott határvárosok térszerkezetét feldolgozó kutatómunka része. ${ }^{2}$ Forrásként elsősorban a helytörténeti munkák építészeti jellegü adatai jöhettek számításba. A két klasszikus, Fényes Elek és Borovszky Samu országleírásai mellett fơként Takáts Sándor, Kecskés László, Pyber Kálmán, Mácza Mihály és Számadó Emese munkáira támaszkodhattam. ${ }^{3}$ Az adatgyüjtést levéltári munka egészítette ki, amelynek során a helytörténeti irodalomban fel nem dolgozott fejlesztési dokumentumok és térképi ábrázolások felgyüjtésére törekedtem a Komárom-Esztergom Megyei Levéltár komáromi fiókjában, valamint a BME Urbanisztikai Tanszék térképtárában. A harmadik forrásanyagot a helyszíni adatgyüjtések, terepbejárások szolgáltatták. ${ }^{4}$ Ennek során váltak megragadhatóvá és értelmezhetővé azok a térbeli és vizuális kapcsolatok, amelyek a Duna mentén ma is léteznek, illetve a térképek alapján következtethetünk egykori meglétükre. Utóbbi kapcsán kiemelendő, hogy a Komáromról igen nagy számban készült képeslapok révén archív fotódokumentációval is rendelkezünk a 20. század első felének városképéről.

\section{KAPUVÁROSBÓL VÉGVÁR (KOMÁROM A 18. SZÁZADIG)}

A Prinz Gyula- és Teleki Pál-féle munkaföldrajz alaptézise szerint a nyugatias civilizáció a Dévényi kapun át lépett be a Kárpát-medencébe. ${ }^{5} \mathrm{~A}$ középkorban kiemelkedően fontos városok láncolatát látjuk a Duna mentén Pozsonytól Pest-Budáig, miközben innen lefelé jellemzően mezővárosokat találunk a vízpartokon. Ennek okát a földrajzi magyarázat a folyó délre fordulásában látja, amely irány nem szolgálja elég hatékonyan a nyugatról keletre haladó tájátalakító munkát. A kultúrák országútjaként müködő Duna természetesen mást jelentett a korai középkorban, a 15. században vagy éppen a török világban. Kovács Péter tanulmányában igen szemléletesen ábrázolja a Duna szerepét a geopolitika változó térképén (1. ábra). ${ }^{6}$ A Magyar

\footnotetext{
${ }^{2}$ Tamáska Máté: Kettéosztott városok tér- és társadalomszerkezete. OTKA PD 108532, 2015-2017, Eötvös Loránd Tudományegyetem.

${ }^{3}$ A bibliográfiai adatokat lásd a konkrét hivatkozásoknál.

${ }^{4}$ A helyszíni kutatómunkát Vajda Barnabás és Beró László történész kollégák segítették. Nyári terepgyakorlat keretében bekapcsolódtak a munkába a győri Szent István Egyetem építész hallgatói is, név szerint Balogh Éva, Botyánszki Zsuzsanna és Fekete Kristóf. A tanulmány szövege támaszkodik a „Komárom/Komárno városépítészeti problémái” konferenciaelőadás anyagára, amely az „Ikervárosok - településegyesítés” konferencián hangzott el, Mosonmagyaróváron, 2014. június 25-én. A nyári terepgyakorlat és a konferenciaelőadás az „Európai Unió és Magyarország támogatásával, az Európai Szociális Alap társfinanszírozásával a TÁMOP 4.2.4.A/2-11-1-2012-0001 azonosító számú Nemzeti Kiválóság Program - Hazai hallgatói, illetve kutatói személyi támogatást biztosító rendszer kidolgozása és müködtetése országos program" címü kiemelt projekt keretei között valósult meg.

${ }^{5}$ Prinz-Teleki 1937. 36.

${ }^{6}$ Kovács P. 2011. 405-414.
} 


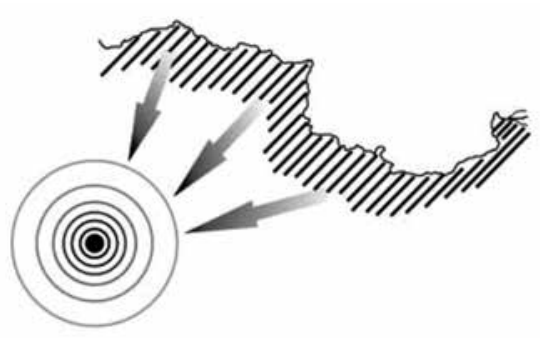

ókor

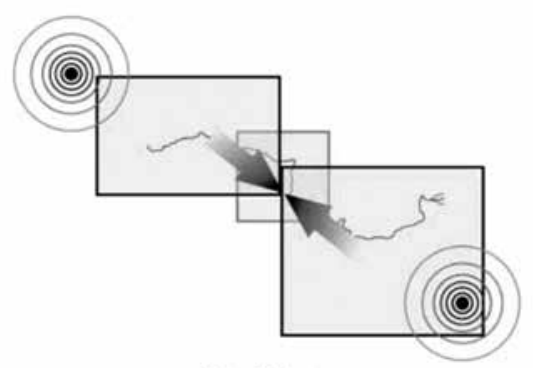

tơrök hódoltság
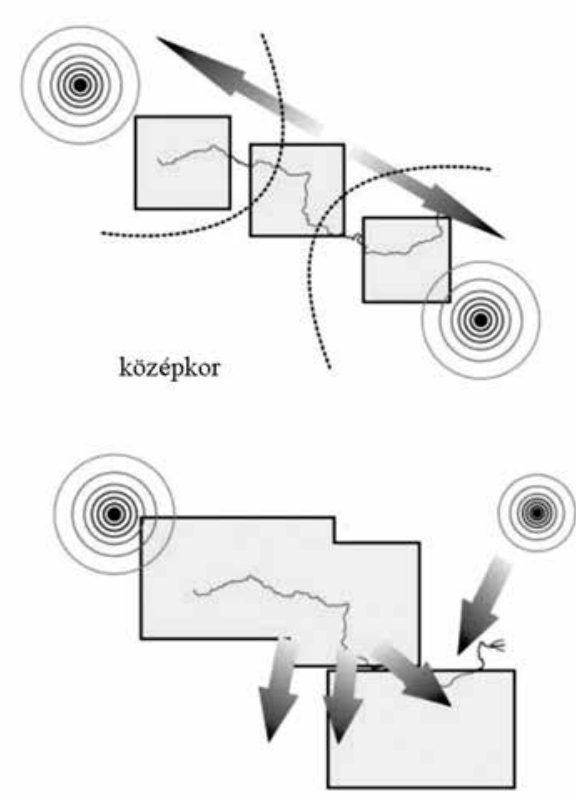

Habsburg-uralom

1. ábra. A Duna régió a geopolitikai erőterében, amely erőtér Komárom fejlődését is meghatározta (Forrás: Kovács P. 2011)

Királyság kialakulását ily módon a Bizánc és a Német-Római Császárság közti szabad dunai tér tette lehetővé. A török elörenyomulása után az 1500-as évektöl ütközőzónává vált a térség, mígnem a 18. században megszilárdult a bécsi központú dunai monarchia. Komárom szerepe e tágabb hatalmi mezőbe helyezve érthető meg igazán: a 15. századig része, de nem kifejezetten jelentős állomása a Magyar Királyság központi településcsoportjának, amelynek sarokpontjait Székesfehérvár, Esztergom és Pest-Buda jelölte ki. ${ }^{7}$ Ez a terület mind földrajzilag, mind társadalomtörténetileg sokkal közelebb állt nyugathoz, illetve a nyugati társadalomfejlődéshez, mint a Pest-Budától délre eső területek. Egyedül a tény, hogy ezen a szakaszon szinte napi járóföldre követték egymást a püspökségek, mint Győr, Esztergom, Vác, illetve a tágabb Duna régióban, Veszprém és Nyitra - miközben innen délre és keletre fél országrésznyi területek kerültek egy püspökség alá -, jelzi, ${ }^{8}$ hogy a Magyar Királyság „ile-de France” területe a Duna Dévény és Pest-Buda közti szakaszára esett. ${ }^{9}$ Komárom fejlődésének akkori helyzeti energiáját legalább annyira köszönhette a Dunának, mint a beletorkolló Vágnak, amelyen keresztül a Felvidék volt elér-

\footnotetext{
${ }^{7}$ Granasztói 1980. 55.

${ }^{8}$ Uo.

${ }^{9} \mathrm{~A}$ francia párhuzamot lásd: Bernard 2003. 223.
} 

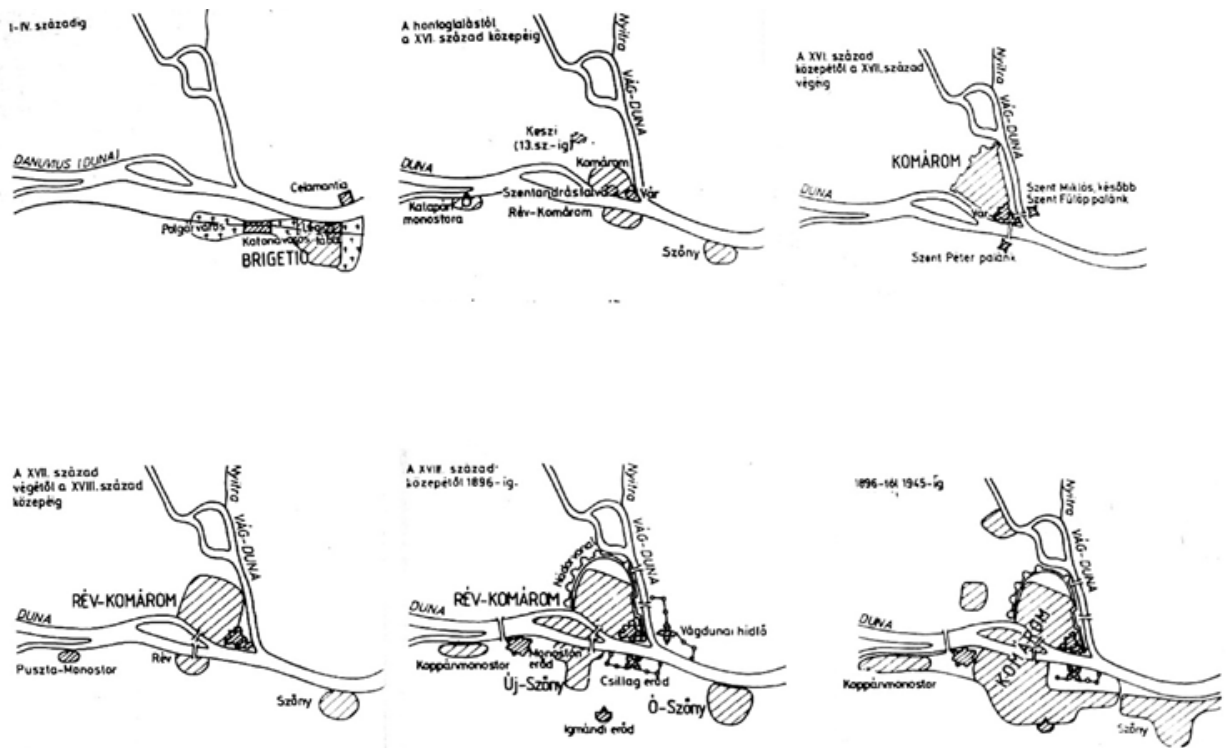

2. ábra. Komárom településcsoportjának fejlödése az ókortól a 20. század közepéig (Forrás: Kecskés 1984. 8-9)

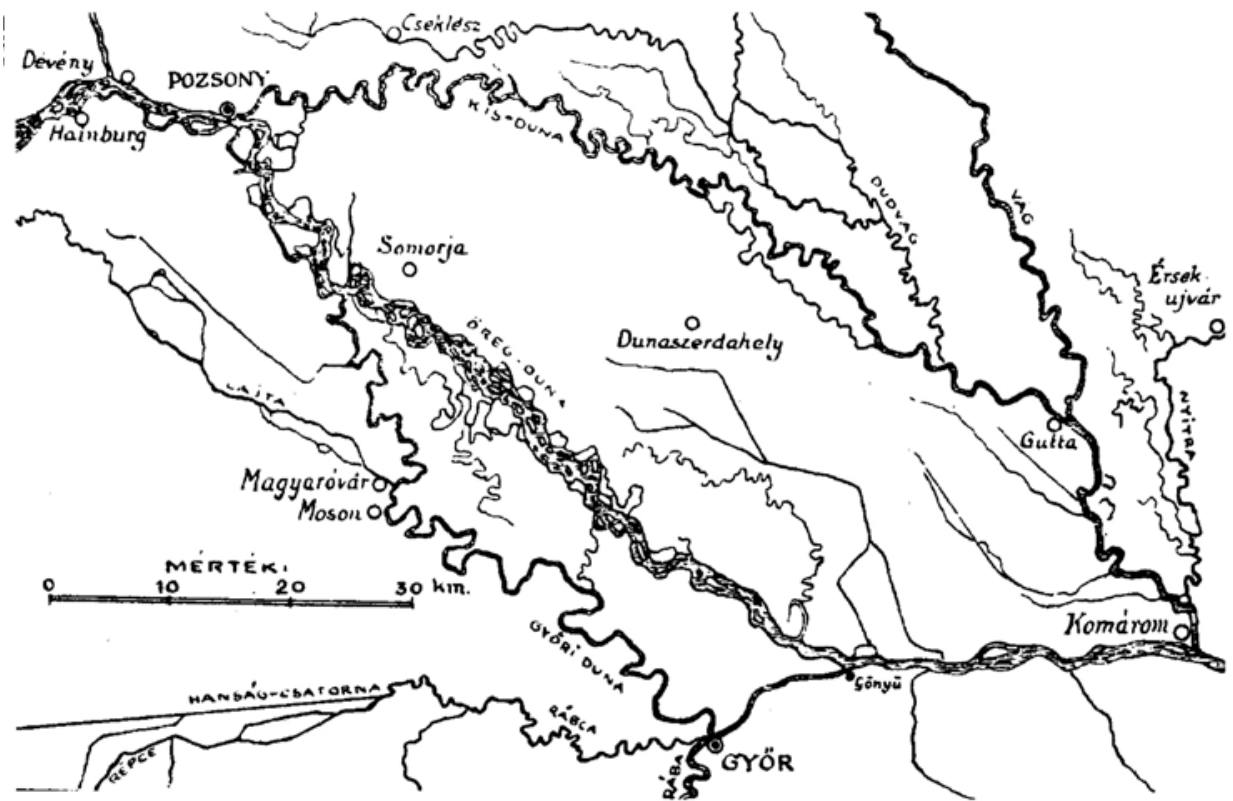

3. ábra. Az alsószakasz jellegủ fő Duna-ág és fattyúágai Pozsony és Komárom között (Forrás: Cholnoky 1940. 252) 
hető. ${ }^{10}$ Kapuváros szerepkörének tudható be, hogy nem a jobb parti római Brigetio romjain (a mai Szőny területén), hanem a Vág-Duna felé közvetlen kapcsolatot jelentő torkolatban épült ki (2. ábra). ${ }^{11}$

Komárom kiépülésének második építési korszaka a 16. századi török terjeszkedéssel veszi kezdetét, mint Habsburg végvár. ${ }^{12}$ 1594-ben Szinán nagyvezér Győr és Tata bevétele után hiába fordul a város ellen. ${ }^{13} \mathrm{~A}$ bevehetetlen várnak ez volt az első komoly sikere, amely okán a modern népszerüsítő tudományos szakirodalomban a „Duna Gibraltárja” nevet kapta. ${ }^{14}$ Komárom védelmét nagyban segítette, hogy a vizek szinte minden oldalról körbefolyták, így szárazföldi erőkkel legfeljebb csak a Csallóköz felöl lehetett volna támadni. A Csallóköz azonban maga is bevehetetlen akadály volt. Pozsony alatt ugyanis a folyó meglassul, a magával hozott hordalékot szétteríti, szigeteket épít, ágakra szakad. Az ilyen alsószakasz jellegü folyamszakaszok a gyakori és kiszámíthatatlan lefolyású árvizek miatt nem kedveznek sem az állandó településeknek, sem az állandó utaknak. ${ }^{15}$ A hajósok is inkább a hordalékkúp két szélén kanyargó fattyúágakat, a Győri- és a Vág-Duna-ágat részesítették előnyben (3. ábra). ${ }^{16}$ Mikor 1594-ben Győr elesett, a dunai folyami útnak csupán a déli ága került török kézre, a Vág-Duna továbbra is császári kézen maradt. ${ }^{17}$ Stratégiai jelentősége okán a várat 1650-1670 között kibővítették, ettől kedve beszélhetünk öregvárról és újvárról. ${ }^{18} \mathrm{~A}$ védelmi igények a Duna túlsó partjait is igénybe vették, így alakult ki a Szent Péter-palánk (a mai Csillagerőd helyén), illetve a Szent Fülöp-palánk (a Vág-Duna keleti partján). Ezek azonban a török kor végeztével elenyésztek. ${ }^{19}$

A legkorszerübb katonai erődítés és az ostromok alatt újra és újra elpusztuló polgárváros kettőssége jellemezte a török kort. Ráadásul a bővülő erődrendszer miatt a polgárvárost fokozatosan nyugatabbra tolták. Közte és a vár között széles várkört alakítottak ki, az ábrázolások szerint vizesárokkal. Míg a középkori Komárom hasonlíthatott a püspökváras szerkezetü Győrhöz, ${ }^{20}$ ahol is a város és a vár egy védelmi rendszert alkotott, addig a 17. század végének Komáromában inkább településpárról beszélhetünk. Ez a kettős, polgári és katonai részre tagozódó alaprajz egyébiránt nem volt ritkaság a hódoltsági területeken. Az azonban már kuriózumnak számít, hogy a megosztottság a 18-19. század egészét végigkíséri.

${ }^{10}$ Lovász 1996. 23.

${ }^{11}$ Lásd: Nagy et al. 2013. 278-286.

${ }^{12}$ Egy 1555-ből származó számadás szerint Komárom a legnagyobb költséggel fenntartott királyi végvár volt, hatszáz főt meghaladó naszádos létszámával pedig hadászatilag is különleges szerepe volt a Duna védelmében. Bánlaky 1927. o. n.

${ }^{13}$ Kecskés 1984. 101.

${ }^{14}$ Lásd: Szénássy 2005.

${ }^{15}$ „A Dunán Pozsony és Komárom között nem lehetett ésszerűen átkelő utat vezetni. Csak Pozsonynál és Komáromnál lehet könnyen átkelni, egyetlen átkeléssel, azért mindkét helyen nevezetes város és vár keletkezett." Cholnoky 1940. 256.

${ }^{16}$ Lásd: Takáts 1900.

${ }^{17}$ Lásd: Szabady 1943. 276-281.

${ }^{18}$ Mácza 1992. 8.

${ }^{19}$ Kecskés 1984. 8.

${ }^{20}$ Eperjessy 1971. 125; Máté 2008. 6-10. 


\section{KOMÁROM ÉS ÚJ-SZŐNY PUSZTA (18-19. SZ.)}

Az 1700-as évek elején Komárom katonai szerepe lecsökken, ám ugyanebben az időben a város sikeresen kapcsolódik be a Duna mentén megélénkülö gabonakereskedelembe. Akkoriban Magyarország egyik legnépesebb települése. Nyolcezer fós lakosságával az ország tíz legnagyobb városa között szerepelt. ${ }^{21}$ Noha a barokk Györnél népesebb volt, városképében alig találjuk nyomát az 1700-as évek építészetének. Mindezt a helytörténeti irodalom az 1763-as nagy földrengéssel magyarázza, amelyet néhány év múlva (1767) tüzvész követett. Az újjáépítéshez a károsultak kénytelenek voltak uzsorára adott kölcsönöket felvenni, ami jelentös elszegényedéshez vezetett. ${ }^{22}$ Új házak esetében a kamara megtiltotta az emeletes házak építését, boltozat helyett sík fafödémet írt elö, de korlátozta a házak sürüségét is. ${ }^{23}$

A város 18. század végi szerkezetéről Vizer János 1800-ban készült térképe nyújt némi képet. ${ }^{24}$ Ezen igen jól kivehető a város csápos szerkezete. Az egyik tengely a Vág-Duna mentén, a másik a Győri-Duna mentén haladt. A két csáp közötti terület nagyrészt üres, illetve ritkán beépült. ${ }^{25} \mathrm{~A}$ térkép másik érdekessége, hogy ábrázolja a vár alatti utcákat, amelyeket 1809-ben a napóleoni háborúk idején elbontottak. ${ }^{26}$ A 19. század elején újra előtérbe került a város katonai szerepe. Így, miközben Európa-szerte sorra bontották el a régi városfalakat, Komáromban minden korábbinál nagyobb erődrendszer kiépítését kezdték meg.

A félsziget csücskét elfoglaló erődrendszer a hídfőerödítések révén átnyúlt a Dunán is (Donau-Brückenkopf, ma Csillag erőd, Waag-Brükenkopf). ${ }^{27} \mathrm{Az}$ erődrendszernek ez a kései reneszánsza egyben azt is jelentette, hogy a polgárváros Komárom számára a 19. század végén, 20. század elején ezek a területek fehér foltnak bizonyultak. Városképileg mindez annál is inkább érdekes, mert a vár és a vele szemben kialakított hídfőbástyák a félsziget tájföldrajzilag talán legszebb részén fekszenek, ahol a két folyóág együttesen belátható, ráadásul a háttérben a Gerecse szelíd dombhajlatai is látszanak. Ám nem csak városképileg, városszerkezetileg is kitüntetett hely lett volna a torkolat vidéke, mivel karnyújtásnyira van Szőnytől, amely - ha már ebben az időben egyesül Komárommal - a maga mezővárosias karakterével jelentösen felgyorsíthatta volna a terület 19 . századi középvárossá válását. ${ }^{28}$

\footnotetext{
${ }^{21}$ Sikos T. - Tiner 2007. 138. A 18. század elejének adatai azonban megtévesztőek Komárom nagyságát és jelentőségét illetően, hiszen az 1715-ös és 1720-as összeírás nem tekinthető mindent szempontból hiteles adatnak.

${ }^{22}$ Bikló 1993. 13.

${ }^{23}$ Borovszky 1907. 142. Mácza Mihály egyébiránt ezt a rendeletet 1783-ra, a második földrengés utánra teszi. Mácza 1992. 9.

${ }^{24}$ Vizer 1800 (térképi dokumentum).

${ }^{25}$ Vizer térképe a középső részt nem ábrázolja, de a második katonai felmérés alapján képet nyerhetünk erről a részröl is.

${ }^{26} \mathrm{Az} 1809$ júniusában Komáromba érkező József nádor naplójába a következőket rögzítette: „300 ház, 3 egész utca leborotválva, $1 \frac{1}{2}$ millióra becsülve." Habsburg Történeti Intézet 2014. o. n.

${ }^{27}$ Lásd: Második Katonai Felmérés (1806-1869) térképszelvénye. Kifejezetten a déli part védelmét szolgálta további két bástya: a Saindberg (Monostori erőd), illetve a Schanzberg (Igmándi erőd).

${ }^{28}$ Lásd bővebben: Herczeg-Számadó-Turi 2007.
} 
A város egyéb területeit is a katonai létesítmények határozták meg. A 19. század elején létesített, úgynevezett Nádor-vonalat messze a Csallóköz felé, a Győri-Duna és a Vág-Duna között húzták meg. ${ }^{29}$ A védett területen belül, közvetlenül a Duna mentén, a pozsonyi kapu előtt néhány évtized múltán már egy új városrészt találunk, egyenes utcákkal és rendkívül kis telekméretekkel. A 18. századi Komárom másik hosszanti tengelye, a Vág-Duna menti azonban éppen a várépítési munkák során veszített súlyából. A 19. században a város fokozatosan a Győri-Duna felé fordult. ${ }^{30}$ A történeti város további sajátossága, hogy a beépítés sürüsége a városszélek felé fokozódott. A lazán beépült, széles tömbbelsőket körülölelö, belvároshoz képest a Nádor-vonalhoz, illetve északon a Kisérhez (kb. a mai vasúti állomás magassága) közeledve a telekméretek csökkennek. Ez a szélekhez tapadó, földszintes kis házakkal teleépített térség azonban minduntalan megbomlott és óriási üres térségnek hagyott helyet, úgymint használatban lévő és felhagyott temetőknek, agyaggödröknek, vásártereknek. Egyedül a Duna-part mentén találunk a belvárostól a Nádor-vonalig húzódó összefüggő településszövetet.

A Duna azonban nem csupán kelet-nyugati tengelyt kínált, de a révátkelő révén egy új városszerkezeti relációt is. ${ }^{31}$ A formálódó két parti város szerkezetét kezdetektől fogva meghatározta a révátkelő, illetve az ehhez kapcsolódó túlparti településrész. ${ }^{32} \mathrm{Az}$ első katonai felmérésen már láthatjuk Új-Szőny első házcsoportját. ${ }^{33}$ A nagy, 1763-as földrengés után még az is felmerült, hogy Komáromot a déli oldalon építsék újra. ${ }^{34}$ Noha erre nem került sor, egyre többen telepedtek meg a déli oldalon. Érdekes, hogy a másik dunai révnél, tehát a Vág-Dunánál nem látunk településkezdeményt. Ennek több oka is lehetett. Egyrészt a vági-révhely vízjárta terület volt, kevés településre alkalmas pontját pedig a katonaság használta, másrészt Új-Szőny kialakulását nemcsak a rév, de a bécsi országút is serkentette. A 19. század közepén Új-Szőny puszta határa mindössze 240 hold volt, ebből következően a kisparaszti fejlődésnek területalapjai sem voltak adottak. ${ }^{35}$ A nyolcszáz fónyi lakosság főként fuvarozásból, hajózásból és napszámból élt. Mikor pedig a vasút viszonylag korán, 1856-ban Győr felől elérte a pusztát, ${ }^{36}$ a kapitalista fejlődésnek szinte valamennyi elvi feltétele adott volt: ${ }^{37}$ Komárom kereskedelmi tradíciói okán jelentős befektetői tőkével rendelkezett, a lakosság egy része tulajdon híján kénytelen volt bérmunkát

${ }^{29}$ „A várerősség, az úgynevezett nádori vonalak (...) körülveszik a várost.” Fényes 1851. 237.

${ }^{30}$ Lásd: Második Katonai Felmérés.

${ }^{31}$ Borovszky 1907. 153.

${ }^{32} \mathrm{Az}$ 1700-as évekből fennmaradt egy ábrázolás, amely nem a mai helyére, hanem közvetlenül a vár alá rajzolta a hidat. Forrás: Jacob Tollius, közli: Kecskés 1984, lásd a számozatlan fényképmellékleteket.

${ }^{33}$ Lásd: Első Katonai felmérés (1763-1787) térképszelvénye.

${ }^{34}$ Borovszky 1907. 143. Más szerzők ezt a tervet a második, 1783-as földrengés kapcsán említik meg. Pyber 1954. 13.

${ }^{35}$ Fényes 1851. 157.

${ }^{36}$ A vasútvonalak fejlődéséről lásd: Számadó-Turi 2010.

${ }^{37}$ Részletesebb kutatást igényelne annak pontos megválaszolása, hogy Szőny iparosodásában mennyire játszott szerepet az északi rész egykori kereskedő rétege, és mennyiben volt az köszönhető más, külső vállalkozói csoportoknak. 


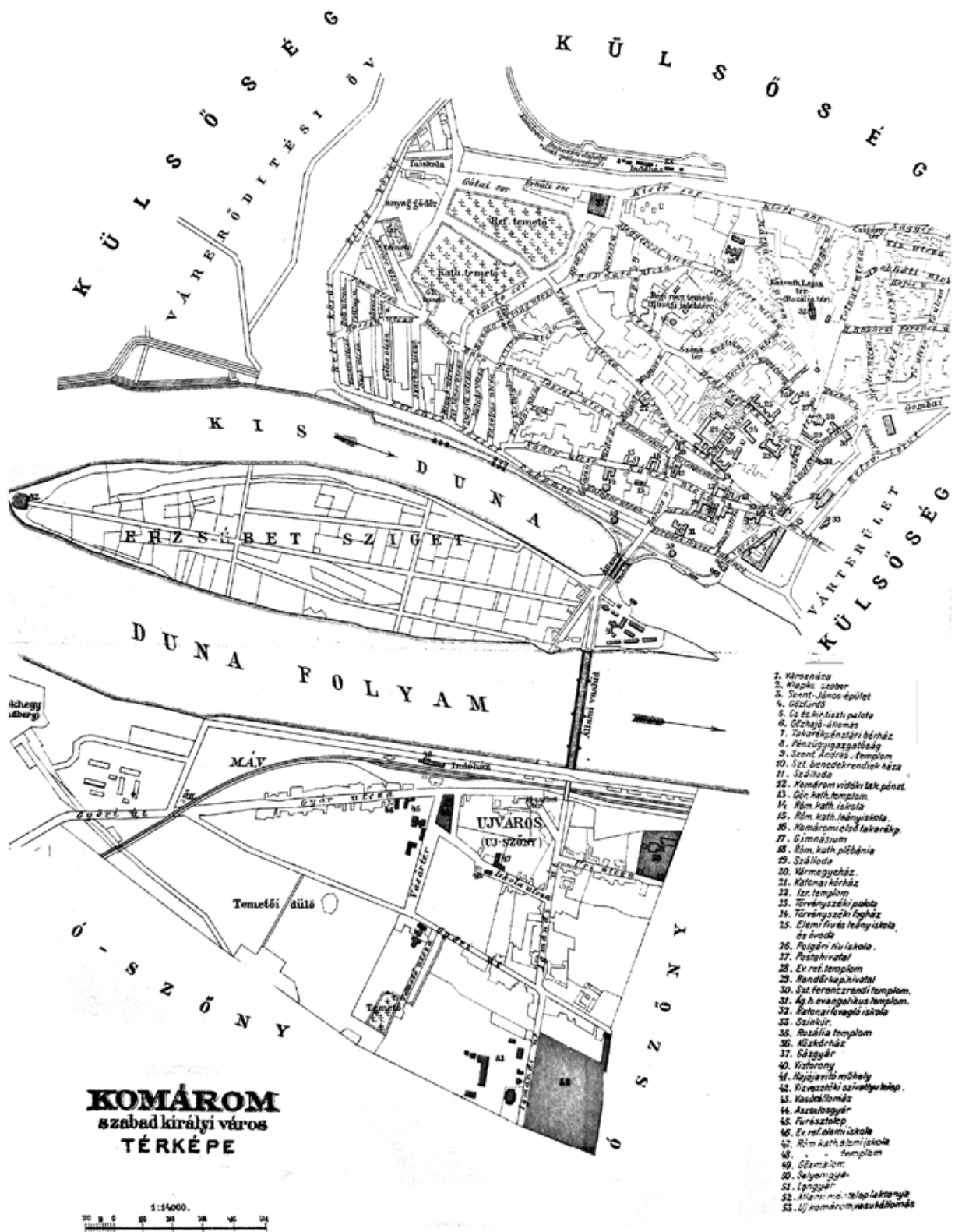

4. ábra. Az egyesített Komárom térképe 1907-ben (Forrás: Borovszky 1907. 140) 
vállalni, a vasút pedig nyereségessé tette a vállalkozásokat. Új-Szőny a következő évtizedekben élénk gyárfaluvá fejlődött. ${ }^{38}$

Mindeközben a történeti Ó-Komárom egyre veszített relatív súlyából. Az 1848/49-es szabadságharc ostromai során okozott pusztításokat nagyon nehezen heverte ki: ,jelenleg alig ismerhetni azon Komáromra, mely 1848-ban állott. Utcái keskenyek és rendetlen menetelüek. (...) Népessége tett 1847-ben 20660 lakost, mely szám jelenleg mintegy 13 000-re olvadt le." ${ }^{39}$ A válságban közrejátszott a vasút, illetve annak hiánya, a dunai hajózás átalakulása, a katonaság erőteljes jelenléte. A patinás Komáromnak a 19. század végén elemi gazdasági érdeke volt a fiatal ÚjSzőny becsatolása a várostestbe, hiszen csak így juthatott iparhoz és forgalmas vasúti összeköttetéshez. ${ }^{40}$

\section{AZ EGYESÍTETT VÁROS (ÓVÁROS-ÚJVÁROS, 1900-1920)}

„Komárom városát a Duna két részre, jobb- és balpartira osztja” - olvashatjuk a Borovszky-féle vármegyei leírásban, amelyet néhány évvel a két város fizikai (1892, Erzsébet híd), törvényi (1896) és tényleges (1900) egyesítése után adtak ki. ${ }^{41}$ Nem tudhatjuk, pontosan, mi vezérelte a szerzőt, hogy az ismertetőjét ezzel a mondattal kezdje, de ott kísérthetett Budapest szintén városegyesítéssel létrejött dunai panorámája. A könyvhöz mellékelt térkép is azt sugallja, hogy a két part nem csupán egy egészet alkotott, de - legalábbis területre - közel egyenlő részét képezte a városnak. Ehhez persze az is kellett, hogy a várat és a várkerületet egészében elhagyják a térképről (4. ábra). A leírás és a hozzá rendelt térkép annál is inkább figyelemre méltó, mert Ó-Komárom - gazdasági válsága ellenére is - nagyságrendekkel jelentősebb település volt, mint a déli oldal. ${ }^{42}$ Innen nézve tehát nem is városegyesítésről, hanem Ó-Komárom terjeszkedéséről beszélhetnénk. A Duna markáns szerkezeti határa nélkül valószínűleg a kortársak is így interpretálták volna a változásokat. Így azonban a folyóparti adottsághoz igazodva egy kétparti város ideája kezdett kibontakozni. Mindez kezdettől fogva nehéz feladatnak ígérkezett. A település méretéhez képest a Duna túlságosan is széles határzóna, amely határzónához könnyen kapcsolódtak szociokulturális identitáselemek. A régi Komárom felső rétegei erős polgári öntudattal bírtak. Jókai Mór, Klapka György hírneve pedig elfeledtette, hogy Komárom voltaképpen már kisváros. Az újvárosnak nem voltak hagyományai, de volt vasútja és voltak gyárai. S noha ezek a gyárak a város büsz-

\footnotetext{
${ }^{38}$ Számadó 2006. 9. A legfontosabb gyárak: az országos jelentőségü Milch-féle fatelep, amely a Vágon lehozott fát dolgozta fel, az állami alapítású selyemfonógyár, majd 1900 után a lenfonógyár, a hengermalom, a keserüvíztöltő és a vasöntő.

${ }^{39}$ Fényes 1851. 238.

${ }^{40}$ Kovács É. 2011. 103.

${ }^{41}$ Borovszky 1907. 154. A Komárom fejezetet Rovács Albin városi levéltáros jegyezte.

${ }^{42}$ 1910-ben északon 18 853, délen 3523 fö élt. 1910-es népszámlás 42. kötet. A népesség főbb adatai községek és népesebb puszták, telepek szerint, 1912.
} 


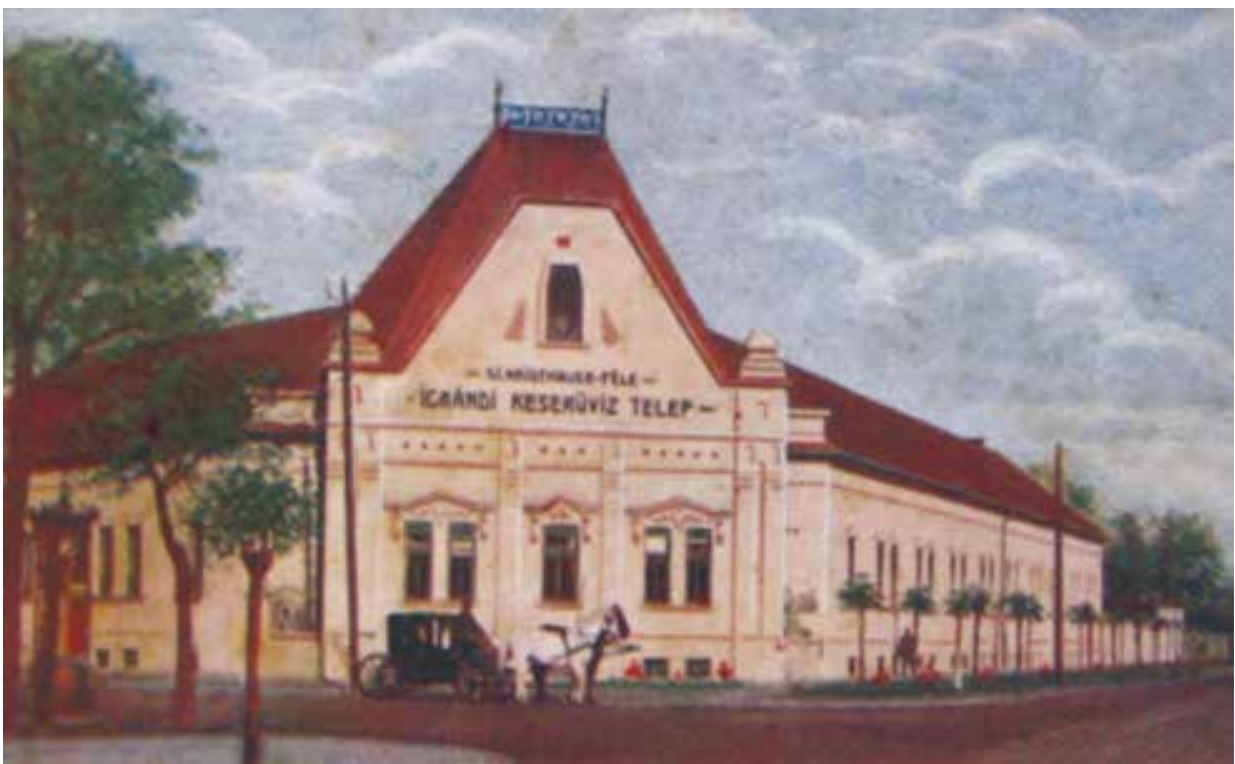

5. ábra. Az Igmándi keserủvíztelep palackozója az újvárosban (képeslap, 20. század eleje, a szerző gyüijteménye)

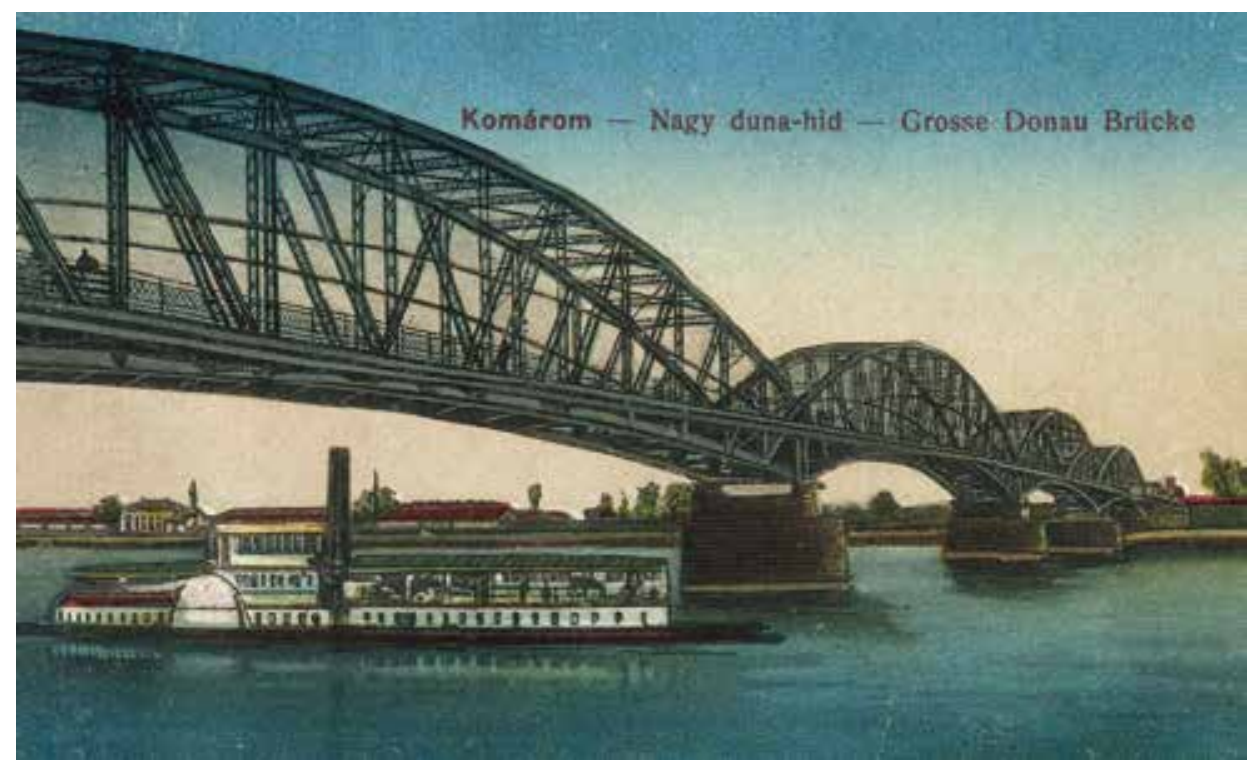

6. ábra. Az Erzsébet híd (képeslap, 20. század eleje, a szerző gyűjteménye) 
keségei voltak, az itt dolgozó munkások inkább félelmet keltettek a polgári rétegekben: ,az újvárosi népesség szaporodása legnagyobb mértékben tekintélyt nem ismerő és teljes szabadsággal élni akaró idegen elemek benépesülése által történik" ${ }^{43} \mathrm{Ha}$ többről nem is szól ez az idézet, arról mindenképpen, hogy a városházán a jobb parti részeket fenntartással kezelték, ami nehezítette a városszövetek amúgy sem problémamentes összefüzését.

Az egykori Új-Szőny vasútvonalainak kiépítésekor nem számoltak a későbbi városegyesítés lehetőségével. Az 1850-es években persze logikusnak tünt a vasutat a komáromi révhez bevinni, majd Székesfehérvár felé továbbvinni. Mikor pedig a harmadik vonalat nyitották meg a fejlődő tatai szénbányák (illetve Budapest) felé az 1880-as években, ezt már a székesfehérvári töltéshez igazították, felépítve a Dunapartra a ma is meglévő teherpályaudvart. ${ }^{44}$ Ó-Komárom folyóparti panorámája, a Szent András-templom impozáns tömbjével, ily módon legfeljebb a vasúton érkezők számára jelenthetett élményt. Holott a modernizálódó dunai városok, így Pozsony, Győr vagy Budapest városképében és identitásában a 19. század végén fontos szerepet töltött be a vízre és az óvárosra egyszerre nyitott túlparti közpark.

Az esetlegesen kialakuló jobb parti településrész további kihívása a szétterültség volt. Annak ellenére, hogy csupán néhány utcából állott, nem volt igazi központja. A hídfő (Erzsébet tér), a Vásártér, a vasúthoz vivő Gyár utca, a Győri országút, az Igmándi út mind egy-egy önálló szerkezeti kezdemény volt, amelynek összeforrasztásához sem idő, sem tervezői szándék nem mutatkozott, annál inkább sem, mert közéjük gyárak és katonai területek ékelődtek. Az újváros akkoriban inkább telepek halmaza volt, amelyek rendszerét a termelés, a közlekedés, illetve a katonaság igényei szabták meg. Jellemző városképi szituáció a központi fekvésü komáromi szikvízüzem (ma Komáromi Nyomda) esete. A gyárépület a város észak-déli föutcájának, az Igmándi útnak értékes saroktelkét foglalta el, de úgy, hogy reprezentatív kialakításával mintha nem is üzem, hanem városi palota kívánt volna lenni (5. ábra). Az identitását és helyét kereső déli városrész nehezen tudott összeforrni az óvárossal, hiszen sem vizuálisan, sem fizikailag nem érintkezett azzal, csupán egyetlen ponton, az Erzsébet hídon keresztül.

A híd megint csak önálló városrész volt (6. ábra). A korabeli képeslapokon úgy ábrázolják, mintha nem is városi, hanem közúti híd lenne. Ténylegesen az is volt, hiszen jórészt állami akarat és erő hozta létre, feladata így kezdettől fogva több volt, mintha városi híd lett volna. ${ }^{45} \mathrm{~A}$ képeslapok azonban némileg csalókák, mivel a széles vasszerkezetre koncentrálnak, amely pedig önmagában nem a két várost, csak az Erzsébet-szigetet köti össze a déli parttal. Márpedig a sziget átalakuló terület volt, amely magában hordozta a várossá válás lehetőségét. Kertjeit régi komáromi polgárcsaládok müvelték, fákkal övezett sétaútja kedvelt polgári kirándulóhelynek számí-

\footnotetext{
${ }^{43}$ Komárom város 1902. évi jegyzőkönyve, 21. számú határozat. Idézi: Számadó 2006.7.

${ }^{44}$ Lásd bővebben: Számadó-Turi 2010.

${ }^{45}$ Hajós 2007. 42.
} 


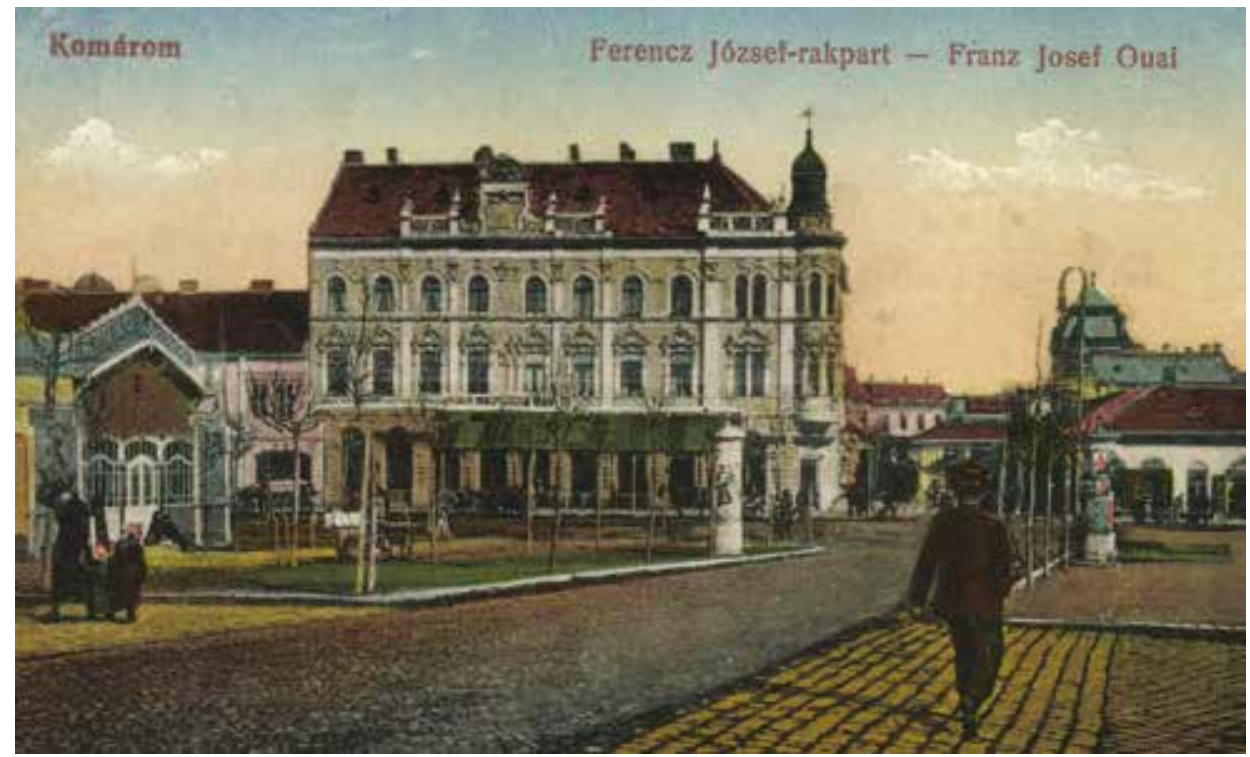

7. ábra. Az ó-komáromi hídfőtér a rakparttal, a Grand kávéházzal és belátással a Baross utcára (képeslap, 20. század eleje, a szerző gyüjteménye)

tott. ${ }^{46} \mathrm{Az}$ itt áthaladó rév mozgalmas, a polgári világtól szociálisan távol álló rétegeket is odavonzott, nem beszélve arról, hogy a szigettel szemközt föként mesterek, hajóácsok, molnárok lakta tarka városnegyed terült el. ${ }^{47}$ Az 1900 -as évek fordulóján a dunai hajózás átalakulása, a téli kikötő s vele a Kis-Duna-ág lezárása, a városi vízmü kiépítése, valamint a rakpartok kövezése miatt a sziget képe alaposan megváltozott. ${ }^{48}$ Mégis azt mondhatjuk, hogy mindezek inkább csak hangsúlyeltolódások voltak, amelyek törvényszerüen együtt jártak a kor városiasodásával. A döntő változást a sziget életében a Magyar Folyam- és Tengerhajózási Részvénytársaságnak 1897-ben Győrből áttelepített javítóműhelye hozta el, amely egy új ipari zónának volt az első lépése. Az Erzsébet-szigeten áthaladó rövid útszakasz így egyszerre két világra nyitott kaput: kelet felé az ipari, nyugat felé a polgári városi tájra. Az 19001945 közötti fél évszázad egyesítésének és kettéosztásának urbanisztikai története voltaképpen nem más, mint a két zóna váltakozó intenzitású kiterjesztése az ó-komáromi hídfö felé. Miközben a századfordulón az Erzsébet-sziget villákkal és parkok-

${ }^{46}$ „Legnagyobb figyelmet érdemel (...) a Dunának (...) a város aljában terülő szigete, mely gőzhajói kikötőn, sétatéren, s a rakodóhelyeken kívül 122 hold és 1037 négyszögölnyi területen, szép gyümölcsös és mulató kertekkel dicsekszik. Fényes 1851. 237. A szigetről lásd továbbá: Takáts 1996.

${ }^{47}$ Mácza 1992. 48.

${ }^{48}$ A folyók iparosítása az elmúlt évtizedekben vált központi témájává a környezettörténetnek. Az egyik legnagyobb hatású ilyen munka: White 1995. 
kal teli polgári világa volt összeolvadóban az északi hídfővel, addig 1920 után a hajógyár fémjelezte ipar terjeszkedése volt megfigyelhető.

A század első két évtizedében tehát az északi hídfő (Kis-Duna híd) körül egy új belváros volt formálódóban, a Baross Gábor utca (7. ábra). Ez az utca a hidat kötötte össze a Nádor utcával, a történeti város kelet-nyugati fötengelyével. A Baross Gábor utca felértékelődése lehetőséget teremtett arra, hogy az eddig hosszában terjeszkedő város az átkelőhely szerepnek megfelelő új centrumot fejleszthessen ki, amely ráadásul fekvésénél fogva a bal parti résznek is inkább központja tudott lenni, mint a városházának otthont adó régi Klapka tér. A rakpartokat kikövezték, a híd két oldalát a korabeli városépítészeti divatoknak megfelelően közparkkal látták el, amit a földmüvelésügyi miniszter neve után Darányi-ligetnek hívtak. ${ }^{49} \mathrm{~A}$ Baross utca, amely egyesítette a tranzit út, a közpark és köztér karakterelemeit, a századfordulós városkép legimpozánsabb alkotása volt, még akkor is, ha az építő energiák csupán a saroktelkek átépítésére voltak elegendőek. Öreg Komárom, amelynek korábban sem a föutcája, sem a fötere nem nézett a Dunára, ebben a két évtizedben kezdett folyóparti várossá lenni. „A Darányi-liget az Alsó-Dunasoron a 19. század második felében és a századfordulón felépült szállókkal, vendéglőkkel, polgárházakkal - kellemes látványt nyújtott a városba érkezőknek." ${ }^{50}$ A kiépülő korzó nyugaton az Erzsébet-szigethez, keleten a várkertben régebb óta müködő Angolkerthez csatlakozott, zöld gyürüt vonva az óváros köré.

A parkgyürü részben a katonai erőd miatt kényszerüségből szabadon hagyott várkör, részben a Duna szabályozása révén jöhetett lére. A zöldterületek rendszere fogta egybe a várost, ez kapcsolta össze a tőle külön fejlődő várral, a Dunával, sőt az Erzsébet-sziget révén a túlparttal is. Az újvárosban ezzel szemben nem létesültek nagyvonalú parkok, mint ahogyan a hídfö kiképzésére is kevesebb gondot fordítottak. Általában is elmondható, hogy dacára annak, hogy a „gravitáció” törvénye szerint a nagyobb óvárosnak kellett volna magához vonzania az újváros szerkezeti vonalait, ennek éppen az ellenkezője történt. Ennek oka pedig, megmaradva a fizikai hasonlatnál, hogy egy harmadik, mindkét településrésznél erősebb vonzás is jelen volt: a vasút és rajza keresztül az országos településhálózat új központja, Budapest. Az óváros a hídon át érintkezett ezzel a világgal, az újváros pedig a vasút, az országút és a katonai létesítmények meglévő adottságainak réseiben tudott csak fejlődni. A település szabályozatlan növekedésére jellemzö, hogy bár jelentős belső területekkel rendelkezett, a „beköltözők” egy része az adóelkerülés miatt a közigazgatási határon túl, a szőnyi részen építkezett. ${ }^{51}$ Egy szabadon fejlödő déli oldal és egy fegyelmezettebb, a hídfö környékén átalakuló északi oldal jellemezte tehát a századelőt.

A városegyesítés utolsó jelentős állomása a vasúti híd megépítése (1913) volt. ${ }^{52}$ A vasúti híddal Komárom visszanyerte korábbi, folyók kijelölte szerepkörét, mint

\footnotetext{
${ }^{49}$ Mácza 1992. 48.

${ }^{50}$ Uo.

${ }^{51} \mathrm{Az}$ úgynevezett Kisszőnyt (az Igmándi erődtől Szőny felé fekvő házcsoportot) végül 1920-ban csatolják Komárom-újvároshoz. Pyber 1953. 22.

${ }^{52}$ I. m. 20.
} 
felvidéki kapuváros. A hidat pedig oly távol vezették a várostesttől, hogy az ne akadályozza a további városnövekedést, mint tették azt a sínpályák a déli oldalon. Az egyesített Komárom szerkezete az 1920-as években még nem volt kész, de magában hordozta a vidéki nagyvárossá válás lehetőségét. ${ }^{53}$

\section{A KETTÉOSZTOTT ÉS ÚJRA EGYESÍTETT VÁROS (Ó-KOMÁROM - ÚJ-KOMÁROM, 1920-1945)}

Komárom 1918-1920-ban lezajlott kettéosztása traumákkal terhes időszak, amit csak tetézett, hogy a helyi konfliktusoknak halálos áldozatai is voltak.$^{54} \mathrm{~A}$ két évtizedet sem megélt egyesített nagy Komárom helyett a Dunához igazított államhatár minden korábbinál élesebb választóvonala nem csupán visszalépést jelentett a városegyesítés menetében, de eddig nem tapasztalt szétfejlődést is eredményezett. Pontos számadatokkal nem rendelkezünk, de közvetlenül a határmódosítást követően megindult a magasan képzett hivatali apparátus áttelepülése a déli oldalra. Új-Komárom népességnövekedése 1910-1920 között 1500 föt tett ki, amely ütem a következő szük két évtizedben is fennmaradt. ${ }^{55}$ Ehhez képest az 1910 elötti népességnövekedés jóval szerényebb mértékü volt. ${ }^{56}$ Ugyancsak az áttelepülés tényét erősíti, hogy ugyanebben az időszakban Ó-Komárom népessége 1500 fövel csökkent. ${ }^{57}$ Kovács Éva kutatásaiból tudjuk, hogy a város kettészakítása jelentős szociális átrendeződést eredményezett. Az Ó-Komáromban kötött magyar házasságok arányszámait tekintve szinte teljesen eltüntek a hivatalnokok, miközben Új-Komáromban jelentőségük hirtelen megnőtt. ${ }^{58} \mathrm{~A}$,ppolgárias” észak és a „proletár” dél közötti osztálykülönbség tehát az 1930-as évekre jelentősen kiegyenlítődött. Ugyancsak kiegyenlítődött a két oldal közigazgatási státusa, amit Ó-Komárom veszteségként, Új-Komárom relatív, de nem teljes sikerként könyvelhetett el. Ó-Komárom a Csehszlovák közigazgatási reform kárvallottja, hiszen az 1923-as megyebeosztással, az úgynevezett „,nagyzsupákkal” elvesztette megyeszékhelyi pozícióját és egy régiónyi terület szélére került, ahol csupán járásközponti szerepét őrizhette meg. ${ }^{59} \mathrm{~A}$ túloldalon Új-Komárom is járási székhely lett, ami azonban ott egyértelmü elörelépést jelentett. ${ }^{60}$ Más kérdés, hogy Komárom-Esztergom vármegye ideiglenes egyesítésével és Esztergom megyeszékhellyé alakításával az is eldőlt, hogy Ưj-Komárom nem fogja megörökölni észa-

\footnotetext{
${ }^{53}$ Komárom a korabeli magyar városhálózat középmezőnyében helyezkedett el, a 39. helyen, Veszprémmel, Nyíregyházával, Zalaegerszeggel, Esztergommal egy csoportban. Beluszky-Györi 2005. 200.

${ }^{54}$ Pyber 1953. 21; Simon 2011. 91.

${ }^{55}$ 1930. évi népszámlálás: Demográfiai adatok községek és külterületi lakott helyek szerint (1932) 1. kötet.

${ }^{56}$ Rédli-Számadó 2010. 41.

${ }^{57} 1941$. évi népszámlálás. Demográfiai adatok községek szerint (1976) 2. kötet.

${ }^{58}$ Kovács É. 2011. 73.

${ }^{59}$ Štenpien 2010. 104.

${ }^{60} 1923$. évi XXXV. törvénycikk a közszolgálatban álló tisztviselők és egyéb alkalmazottak létszámának csökkentéséröl és egyes kapcsolatos intézkedésekröl. Ezer év törvényei. http://www.1000ev.hu/ (Utolsó megtekintés: 2016. 01. 17.)
} 


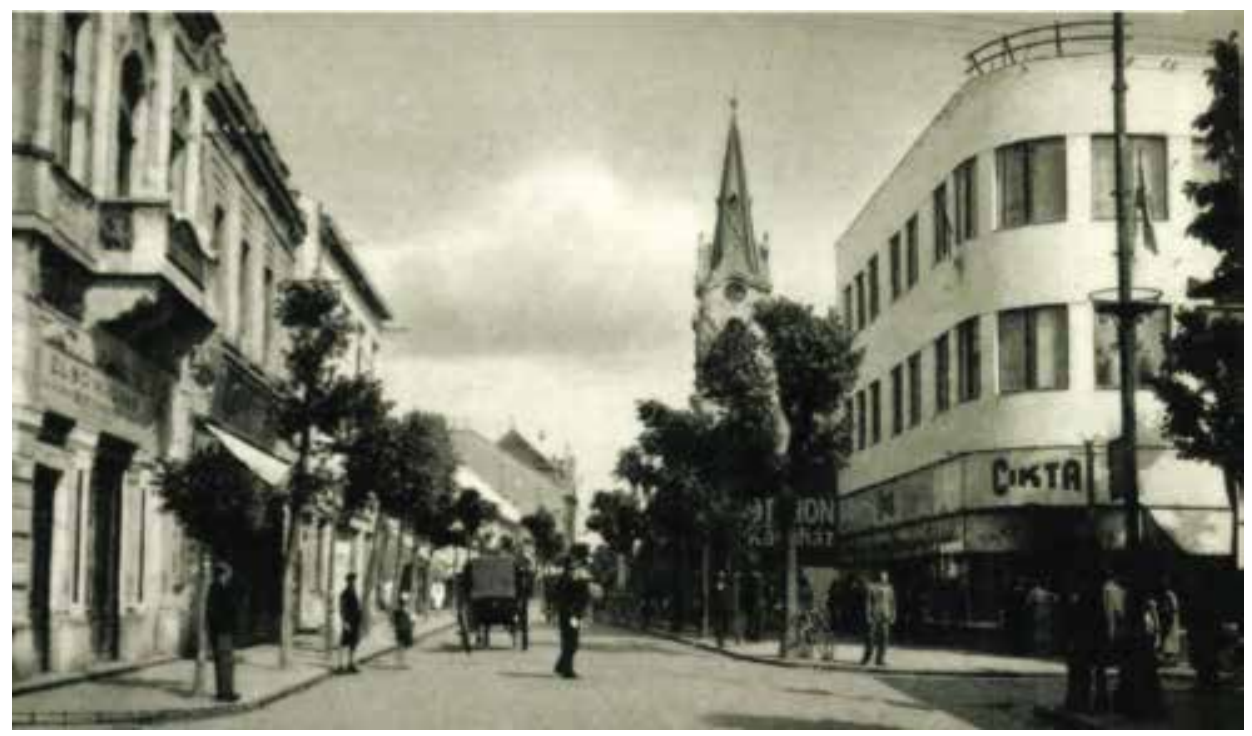

8. ábra. A volt Bata, 1938 után Cikta cipőáruház a Nádor utca és a Baross utca sarkán (képeslap, 1940-es évek, a szerző gyüjteménye)

ki felének központi pozícióját. A kettészakított részek népesedési trendjeit, szociális átrendeződését és a közigazgatási státusok változását figyelembe véve logikusnak tünik, hogy a két világháború közötti évtizedet egy stagnáló ó-komáromi városkép és egy dinamikusan változó Új-Komárom jellemezte.

Valóban igaz, hogy Ó-Komárom alapszerkezete érdemben nem változott a két világháború között, noha a városszéleken erőteljes telepszerü családi házas építkezések zajlottak. ${ }^{61}$ A belváros képe keveset változott, ám ez a kevés is elegendő volt ahhoz, hogy Ó-Komárom „csehszlovák”, vagy ahogyan a kortársak hívták „,cseh” városi karaktert kapjon. Akárcsak a századforduló, úgy az 1920-38 közötti időszak emblematikus épületei is saroktelekre kerültek, így biztosítva a lehető legkisebb energiabefektetéssel a lehető legnagyobb figyelmet. A Baross utca - Nádor utca sarkán, tehát a történeti és a századfordulós főutca sarkán kapott helyett a „csehszlovák modernt" képviselő Bata áruház (8. ábra). Az épület lekerekített homlokzatával, világos falfelületeivel és keret nélküli ablakaival a korabeli Prágát juttatja az ember

\footnotetext{
${ }^{61}$ Elsősorban a vasút körüli területen volt intenzív építési tevékenység, de épültek tisztviselőházak a cseh hivatalnokoknak, illetve a Nádor-vonalon túl, a pozsonyi út mellett munkástelkeket mértek ki. „1921-ben 1774, 1930-ban pedig 2276 ház volt a város belterületén." Mácza 1992. 14. 1938-ra ez a szám tovább emelkedett és már alig maradt el a háromezertől (2948). Lásd: Földbirtok-összeírás: Az 1938. évi felvidéki nép-, földbirtokés állatösszeírás az 1938. november 2-i bécsi döntés alapján visszacsatolt területen végrehajtott összeírás eredményei községek szerint (1939). A statisztikák szerint tehát a házállomány meglehetősen dinamikusan növekedett, lényegesen gyorsabban, mint a túlparti oldalon, ahol 1930-ban is csupán 872 ház állott. Lásd: 1930. évi népszámlálás. A számok jelezte különbség okainak feltárása azonban meghaladná jelen tanulmány kereteit.
} 
eszébe. ${ }^{62}$ Távolabb áll a cseh és közelebb a nemzetközi modern szellemiségéhez a Szentháromság-szobor mögötti telekre került vasbeton lépcsős lakóház. Bierbauer Virgil, aki az 1938-as visszacsatolás után tárcában mutatta be Komárom alapvető esztétikai problémáit, mint rossz példát, külön is kiemelte a történeti városképhez nem illeszkedő épületet. ${ }^{63} \mathrm{~A}$ két épület felkiáltójel volt a városképben. Szimbolizálták Csehszlovákiát, amely egy új és racionálisabb világot hirdetett a régi magyar uralom helyén. Márai Sándor találóan „Bata-cipős demokráciáról” írt, egy olyan ésszerü, de idegen világról, amely világosan szemben állt a régi Magyarországnak nemcsak nemzeti berendezkedésével, de társadalmi értékrendjével, szokásaival, mindennapi normáival is ${ }^{64}$ Más olvasatban persze azt mondhatnánk, hogy a kisebbségi magyarság kényszerből ugyan, de hamarabb talált rá azokra az utakra, amelyeken keresztül a rendi társadalmat és vele együtt annak eklektikus és szecessziós építészetét elhagyta.

Ugyanebben a két évtizedben Új-Komárom a Wälder Gyula-féle neobarokktól az olasz mintákból táplálkozó monumentális neoklasszicizmusig jutott el, ami persze nem nélkülözte a modern építészet hatását sem. Az elsőre a polgári iskola (1927) és a városháza (1929), az utóbbira a Jézus Szíve-templom (1937) említhető példaként (9. ábra) ${ }^{65}$ A monumentális hatásokkal dolgozó épületeket látva Ikvay László komáromi katolikus pap ${ }^{66}$ a következő sorokat vetette papírra 1939-ben: „Barátságtalan gőggel bámultak le ránk ezek az épületek, és mi farkasszemet néztünk az idegen cikornyáikkal. (...) A teret betöltötte az a lelkiség, amit Szekfü Gyula neobarokknak nevez: a magyar dekadencia (...) Mint élő anakronizmus meredt felénk egyre idegenebbül egy koncepció és mondanivaló nélküli kornak (...) pöffeszkedő önáltatása. A háború utáni Csonkaország reprezentatív stílusa." ${ }^{67}$ A „neobarokk” sokak számára mind a mai napig negatív jelzőként hat, ami megnehezíti a két világháború közt kiépült Új-Komárom városképi értékeinek elfogadását. Jellemző, hogy Komárom hivatalos mủemlékei között egyetlen két világháború közti alkotást sem találni. ${ }^{68}$

${ }^{62}, \ldots$ az egész országban általánosan használt modern építészeti nyelv a nemzeti egység képzetét is sugallta, függetlenül attól, hogy ez az egység inkább csak a vágyak világában létezett. Ferkai 2003. 162.

${ }^{63}$ Bierbauert (Borbírót) ítéletében biztosan nem a modern építészet elleni kirohanás vezértelte, hiszen más környezetben maga is híve volt az új építészetnek. Bierbauer 1941. 5.

${ }^{64}$ Márai Sándor: Ajándék a végzettől. Idézi: Simon 2011. 93.

${ }^{65}$ Wälder Gyula stílusáról két jellemző momentum: „egyéni neobarokk stílusát a kortársak (...) »iparbarokknak « nevezték el, utalva részben rengeteg megbízására, részben pedig (...) elöre gyártott épületdíszeire. (...) munkái figyelembe veszik a vidéki városok léptékét és hangulatát.” Sisa-Wiebenson 1998. 276. - A Jézus Szíve-templomot tervező Körmendy Nándorról pedig a Magyar Katolikus Lexikon így ír: „Kockás térelemekből szerveződő, dísztelen, monolit épületei az itáliai novecento építészeti gondolatának átültetései” - Magyar Katolikus Lexikon, internetes kiadás, lexikon.katolikus.hu (Utolsó megtekintés: 2016. 01. 17.) - A két világháború közti időszak további fontos középületei: önkéntes tüzoltóság (1926), pénzügyőri hivatal (1928), ipartestületi székház (1928), rendőrségi palota (1928), járásbíróság (1930), strandfürdő (1935), zeneiskola (1937).

Rédli-Számadó 2010. 44.

${ }^{66}$ Ikvay Lászlóról lásd: Hollai 1996.

${ }^{67}$ Ikvay László: Újkomáromi kontraszt (felszabadulási élmény). Idézi: Simon 2011. 93.

${ }^{68}$ Haris-Somorjay 2006. 77-80. 


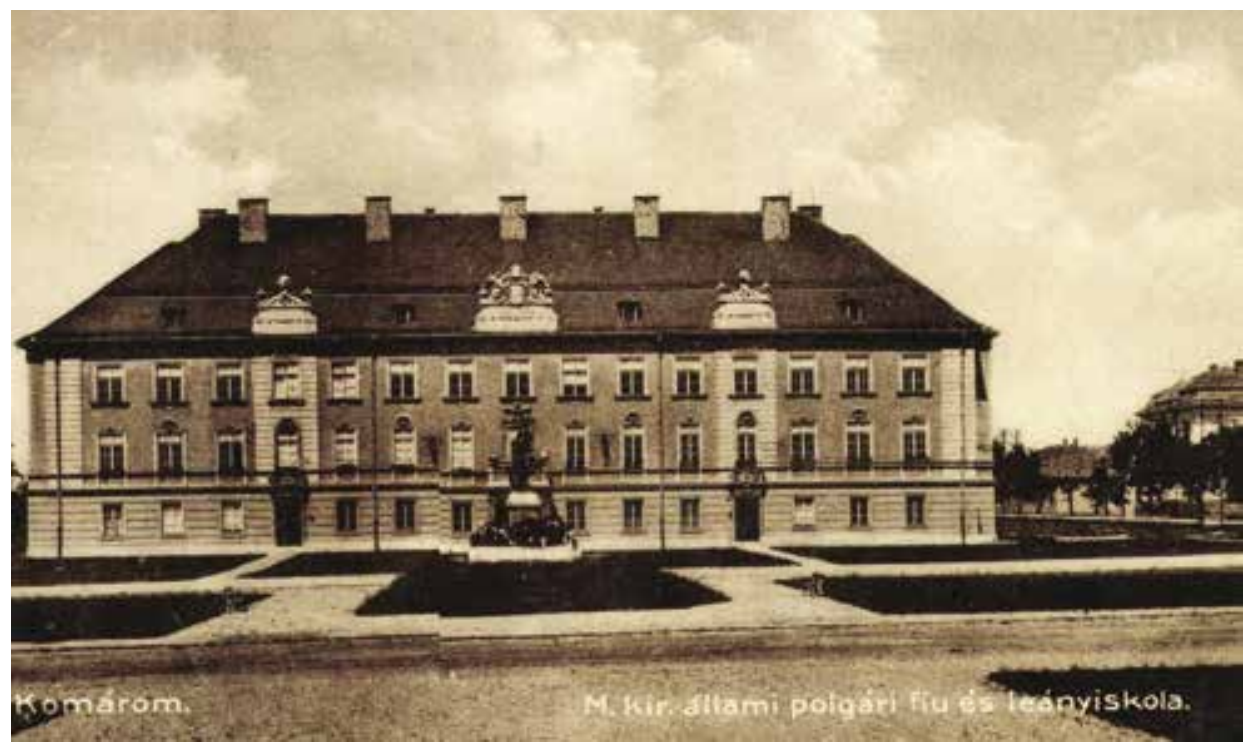

9. ábra. Magyar Állami Fiú- és Leányiskola Új-Kormáromban (képeslap, 1930-as évek, a szerző gyüjteménye)

Az építészeti nívó körüli polémiánál is fontosabb azonban annak megállapítása, hogy Új-Komárom városközpontjának kialakításakor - a revizionista retorika ellenére - nem számoltak az újraegyesítés lehetőségével: „1920 után a magyar kormányok törekvése, hogy a megmaradt jobbparti külvárost segítse (...), a mai helyzetből tekintve újabb átok lett a városra. (...) Ó-Komárom város bejárata csaknem két kilométerre van Új-Komáromnak a húszas évek végén kiépített városközpontjától." ${ }^{69}$ Pedig központként kínálkozott volna az Erzsébet tér (a mai Tesco áruház környéke), amely spontán módon fejlődő hídfőtér volt. ${ }^{70}$ Reprezentatív kiépítésével tükörtere születhetett volna meg az északi Baross utcának. A további kutatásoknak kell majd kiderítenie, miért nem alkalmazkodott a városfejlesztés ehhez az adottsághoz. Legvalószínübb válasz, hogy a menekült városban nem volt idő a tervezésre. A nagyszámú menekült és átköltöző gyors telekhez juttatása a legegyszerübb megoldást részesítette előnyben. A Szőnytől átcsatolt földeken, az országút mellett mérték ki a sakktáblaszerü új várost, amelynek közepére került a már említett neobarokk fötér.

A régi Új-Szőny magjától való eltávolodást a harmincas években már korrigálni igyekeztek. Egy 1932-re datált rendezési térkép tanúsága szerint az Erzsébet téren lévő tömbtelek megnyitásával egy „,körönd” jellegü közlekedési föteret hoztak volna létre, amely a híd, az Igmándi út, a katolikus kistemplom és iskola között teremtett

${ }^{69}$ Bierbauer 1941. 4.

${ }^{70} \mathrm{Az}$ Erzsébet tér ma már nem felismerhető egykori „,Y” formáját annak köszönhette, hogy a korábbi hajóhíd nem pontosan a mai Erzsébet híd vonalában, hanem mintegy 50-60 méterrel nyugatabbra kelt át a folyón. 
volna kapcsolatot. ${ }^{71}$ Ám még ezen az elképzelésen sem találjuk nyomát az esetleges újjáegyesítés gondolatának, sőt, mintha a cél egy önállóan is életképes város létrehozása lett volna. A hídtól induló észak-déli főtengely, az Igmándi út helyett egy új, a vasútállomástól indított sugárút épült volna ki, amely elvezette volna a várost a Dunától és vele együtt az Ó-Komáromba vezető hídtól is. A sugárúthoz csatlakozó, átlós összeköttetésekkel operáló utcarendszer szomszédsági elven müködő városrészeket irányzott elö, egyiket egy fötérrel, a másikat egy sétánnyal összefogva. Hasonló sétányokat és tereket találunk a térképen a Szőny felé eső városrészben is.

A térképen még nem szerepel Koppánymonostor, amelyet pedig éppen 1932-ben csatoltak az újvároshoz. ${ }^{72} \mathrm{Az}$ egykori szőlőheggyel való egyesítés társadalmilag érthető volt, hiszen az itteni lakosság föképp volt komáromi lakosokból verbuválódott, ám városszerkezetileg komoly ballaszt képződött, hiszen nyugat felé hosszan kihúzta a belterületet. Az amúgy is jelentős távolságot a régi Új-Szőny és Koppánymonostor között tetézte a köztük fekvő Monostori erőd, amely a város számára idegen területnek számított. Annyi előnye azonban mindenképpen volt az egyesítésnek, hogy ezzel végre egy szabad Duna-parthoz jutott Új-Komárom, ami a pályaudvarokkal határolt belvárosból hiányzott. ${ }^{73}$

Miközben Új-Komárom, ha nem is a szüken vett belső részeken, de végül értékes, a későbbi, a 20. század második felében lezajlott városfejlődés számára felhasználható Duna-parti területekkel gazdagodott, Ó-Komárom belvárosa a két világháború között elveszítette meglévő, parkokkal kiépített Duna-partját. A még a magyar időkben épült lőszergyár a Vág-Duna mentén kelet felé jelentett éles határzónát. ${ }^{74}$ A Győri-Duna felé azonban továbbra is élénk volt a belváros vízparti kapcsolata. 1922-ben azonban a várostól a Csehszlovák állam átvette a területet és ott nemzetközi kikötöt létesített, iparvágányokat fektetett le. ${ }^{75} \mathrm{~A}$ harmincas években az iparvágányok úgy ölelték körül Ó-Komáromot és föként annak Duna-parti térfalait, mint fél évszázaddal korábban tette ezt az erődítésrendszer (10. ábra). Ha kezünkbe vesszük az 1943-ban készült, ismét egyesített város átnézeti térképét, azt látjuk, hogy a belterület egy nagyvároshoz illő belső sínhálózat szorításába került. ${ }^{76}$ Ennek felszámolása, illetve áthelyezése lett volna az újbóli városegyesítés legsürgetöbb infrastrukturális feladata, hogy végre Komárom azzá válhasson, aminek egyesítésekor megálmodták: a Duna partjait megülő folyami várossá. „A Dunától körülfolyt Komáromban a Dunát nem látni. (...) Komárom hátat fordít a Duna partnak, meg a szigetnek, amelyből földi paradicsom lehetne!" - írja Bierbauer Virgil már idézett tanulmányában. ${ }^{77}$ Bierbauer készítette az egyesített városrendezési tervet is, amelynek súlyos problémák sorát kellet volna orvo-

\footnotetext{
${ }^{71}$ A körforgalmi fötér gondolata később a szocialista várostervezés idején valósulhatott meg, de nem itt, hanem az egyes főút és az Igmándi út kereszteződésében. Komárom térképe 1932.

${ }^{72}$ Rédli-Számadó 2010. 47.

${ }^{73}$ Koppánymonostor ma a városon belüli szuburbanizáció tipikus célterülete.

${ }^{74}$ Természetesen az ipari területeknek is megvan a városképi, városszerkezeti jelentősége.

${ }^{75}$ Mácza 1992. 48.

${ }^{76}$ Komárom átnézeti térképe 1943.

${ }^{77}$ Bierbauer 1941. 6.
} 


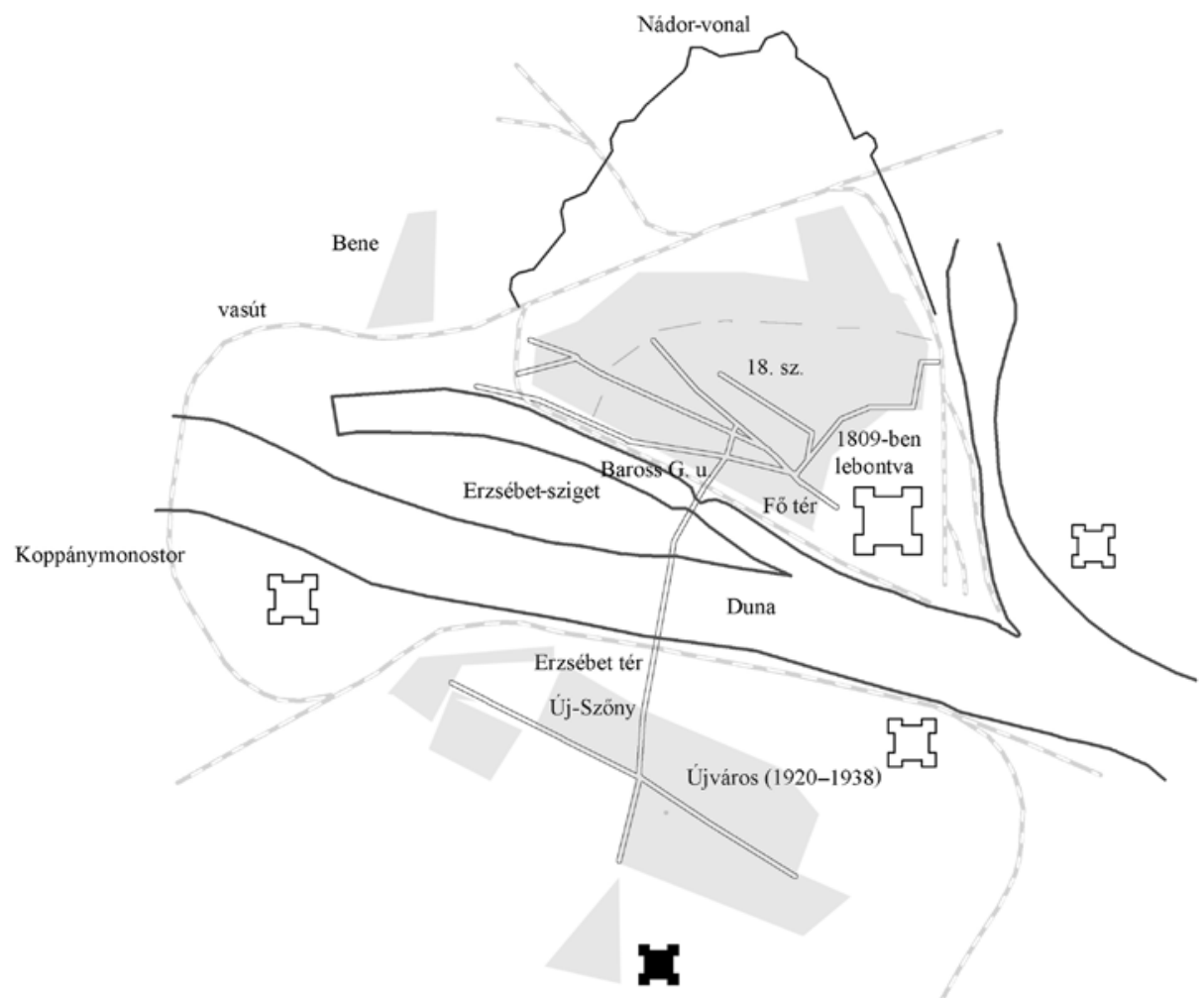

10. ábra. Az újraegyesített Komárom térszerkezeti vázlata az 1940-es évek elején (a szerző szerkesztése Komárom átnézeti térképe 1943 alapján)

solnia. ${ }^{78}$ Sajnos az eredeti terveket mind ez idáig nem sikerült felkutatni, ezért csupán tanulmányára és az 1943-as térképre támaszkodva feltételezhetjük, hogy az újraegyesített városban a Duna-parti ipari területek felszámolása, illetve városszélre helyezése lett volna a legjelentősebb beavatkozás. A felszabadult területeken pedig parkok és sportpályák sorakoztak volna. A két városrész közötti fizikai távolság problémáját rendszeres trolibuszjárat oldotta volna meg. Bierbauer elképzelése szerint a túlzsúfolt Ó-Komáromból Új-Komáromba kellett volna koncentrálni a lakásépítési energiákat, hogy ott egy modern kertváros születhessen.

Az elveket azonban a gyakorlat felülírta. Az 1940-es években Ó-Komárom lakónegyedei a háborús viszonyok ellenére is dinamikusan terjeszkedtek, föként családi házas telepek formájában. A Nádor-vonal I-es bástyájának lebontásával a város megnyílt nyugat felé. ${ }^{79} \mathrm{Az}$ itt kimért, úgynevezett „Bene” utcáit a negyvenes években még csak számok jelölték. Ez a telep volt a legtávolabbi, de máshol is megfigyelhető

${ }^{78}$ Artportal - Lexikon 2014. o. n.

${ }^{79}$ Mácza 1992. 15. 
volt a külsőségek területtartalékainak beépítése. S mivel ezek a tartalékterületek rendre messze estek hídtól, semmiképpen sem járultak hozzá a két part összeolvadásához. ${ }^{80}$ Elmondható, hogy az 1938-1945 közötti második városegyesítés az idő rövidsége és az 1920-38 közötti évek szétágazó társadalmi és morfológiai öröksége okán nem tudott olyan szerkezeti és társadalmi átalakulásokat generálni, mint a fél évszázaddal korábban egyesített első nagy Komárom. Az idő sem volt alkalmas a várostervezés számára, hiszen a háborús viszonyok, a besorozások és a deportálások, a bombázások és a frontharcok sokkal inkább a pusztulásnak, semmint az építkezésnek nyitottak teret.

\section{ÖSSZEFOGLALÓ}

Történeti áttekintésünk végén azt a konklúziót kell levonjuk, hogy Komárom város történeti fejlődése nem alakított ki szoros kapcsolatot a város morfológiai megjelenése és a Duna-part között. A településpár sem a Vág-Duna, Győri-Duna összefolyásában, sem az Erzsébet-sziget menti partszakaszon nem tudott vizuálisan átlátható és a lakók által használható város-folyó kapcsolatot létrehozni. Ennek időben legelső oka, hogy a 19. században folyamatosan bővülő erődrendszer lezárta a városszövetet és ezzel degradálta a dunai kapcsolatokat. (Más kérdés, hogy mai szemmel, mint kulturális örökség, az erőd jelentős értéket képvisel.) Ó-Komárom a két Duna-ág torkolatába ékelődve megkapóan harmonikus település-táji környezetben épülhetett volna fel, föként, ha már az 1800-as évek közepén megindult volna egyesülése a túlparttal. A második ok a vasútépítés, amely újabb gyürüt vont a város és a vízpartok közé, bár tény, hogy ez a gyürü 1920-ig inkább csak a déli partra volt jellemző. Sőt a városegyesítés két évtizedében, 1900-1920 között Ó-Komárom rövid időre megnyílt a hídfö és vele együtt a túlpart irányába. Talán nem véletlen, hogy a „Csehszlovák” időkben éppen ezt a területet zárták el a várostól, kikötőként és egyéb ipari zónaként kezelték, ami a politikai határt erősítő morfológiai és vizuális határt eredményezett. Ugyanakkor a másik oldalon meglepő, hogy Új-Komáromban sem számoltak a két parti városszövet sajátos szempontjaival, holott a revíziós politikában az újraegyesítés kívánatos célként fogalmazódott meg. Mikor ez 1938-ban bekövetkezett, a várostervezési problémák halmazát kellett volna rövid időn belül megoldani ahhoz, hogy a két oldal a Duna felé forduljon és ott közös városi tereket hozzon létre. Ez azonban nem sikerült, részben a háború, részben a mentális és morfológiai határok miatt sem, amelyeket ilyen rövid idő alatt lehetetlen volt feloldani. Jól jelzi ezt, hogy bár Ó-Komárom az 1940-es években intenzíven terjeszkedett, de nem a túlpart irányába, hanem saját belső területtartalékait felhasználva, a Csallóköz felé. Komárom tehát arra is példa, hogy az 1920-as évektől befelé forduló városszövetek a város közigazgatási ideiglenes újraegyesítése után is ható ballasztokat eredményeztek.

\footnotetext{
${ }^{80}$ 1944-ben csatolták a városhoz a szomszédos külterületeket: Benetelep, Érsekújvári út, Kisharcsági út, Kisszőnyi dűlő, Partosújtelep, Szérüskert, Vágdunasziget. Lovász 1996. 23.
} 


\section{HIVATKOZOTT IRODALOM}

Artportal - Lexikon 2014 http://artportal.hu/ (Utolsó megtekintés: 2016. 01. 19.) A szócikket készítette: Tölgyes Orsolya.

Bánlaky József: A magyar nemzet hadtörténelme. Budapest 1927. Elektronikus kiadás megtalálható Magyar Elektronikus Könyvtár, http://mek.oszk.hu/ (Utolsó megtekintés: 2016 .01. 03.)

Beluszky Pál - Győri Róbert: Magyar városhálózat a 20. század elején. Dialóg Campus Kiadó, Budapest-Pécs 2005.

Bierbauer Virgil: Vidéki városok. Komárom példája. Különnyomat a Magyar Szemle 1941. decemberi számából. Budapest 1941. 1-7.

Bikló István: Komárom város tüzvédelmének története. Komáromi Városszépítő Egyesület, Komárom 1993.

Borovszky Samu (szerk.): Komárom vármegye és Komárom sz. kir. város. Országos Monografia Társaság, Budapest 1907.

Braudel, Fernand: Franciaország identitása I. A tér és a történelem. Helikon Kiadó, Budapest 2003.

Cholnoky Jenő: A csillagoktól a tengerfenékig III. Hegyek-völgyek. Franklin Kiadó, Budapest 1940.

Eperjessy Károly: Városaink múltja és jelene. Müszaki Kiadó, Budapest 1971.

Első Katonai Felmérés. A Habsburg Birodalom történelmi térképei. mapire.eu (Utolsó megtekintés: 2016. 01. 17.)

Ferkai András: Kelet-Európa tanulsága. In: Ür vagy megélt tér. Épitészettörténeti irások. Szerk. Ferkai András. Terc Kiadó, Budapest 2003. 160-173.

Fényes Elek: Magyarország geographiai szótára. Nyomatott Kozma Vazulnál, Pest 1851.

Granasztói György: A középkori magyar város. Gondolat Kiadó, Budapest 1980.

Habsburg Történeti Intézet (szerk.): Komárom, a katonaváros - Elözetes tanulmány. Történeti Intézet. http://www.habsburg.org.hu/szakmai együttmüködések 4. pont (Utolsó megtekintés: 2016. 01. 10.)

Hajós Bence et al.: Hídjaink a római örökségtöl a mai óriásokig. Közlekedésfejlesztési Koordinációs Központ, Budapest 2007.

Haris Andrea - Somorjay Sélysette: Magyarország müemlékjegyzéke. Komárom-Esztergom megye. Kulturális Örökségvédelmi Hivatal, Budapest 2006.

Herczeg Renáta - Számadó Emese - Turi Zsolt: Komárom és településrészeinek egyesülése. Szöny és Koppánymonostor története a kezdetektöl 1977-ig. Klapka György Múzeum Katalógusai VII. Komárom 2007.

Hollai Ferenc: Ki volt Ikvay László? (1996) http://www.ppek.hu/ (Utolsó megtekintés: 2016. 01. 17.)

Kecskés László: Komárom az erődök városa. Zrínyi Katonai Kiadó, Budapest 1984.

Komárom átnézeti térképe 1943. BME Urbanisztikai Tanszék Könyvtára. T 363.

Komárom térképe 1932. Komárom-Esztergom Megyei Levéltár. Komáromi fiók. Térképtár, I/9.

Kovács Éva: A határ és a „házassági piac”; Határváltó diskurzusok Komáromban (1918-22, 1938). In: Államhatár és identitás - Komárom/Komárno. Szerk. Vajda Barnabás. Monographiae Comaromienses 3. Selye János Egyetem Tanárképző Kara, Komárom 2011. 59-98; 99-132.

Kovács Péter: A Duna szerepe Közép- és Délkelet-Európa térfejlődésében. Földrajzi Közlemények 135 (2011) 4. 405-414.

Lovász János - Dávid Zoltán: Magyarország történeti statisztikai helységnévtára. Komárom-Esztergom megye. KSH-MTA, Budapest 1996.

Mácza Mihály: Komárom. Történeti séták a városban. Madách Kiadó, Pozsony 1992.

Második Katonai Felmérés. A Habsburg Birodalom Történelmi Térképei. mapire.eu (Utolsó megtekintés: 2016. 01. 11.)

Máté Zsolt: A történelmi magyar városok alaprajzi tipológiája. Örökség 12 (2008) 7-8. 6-10.

Nagy Balázs - Deák Márton - Viczián István - Jámbor Zsófia - Rupnik László: A jó időben a jó helyen: Duna-menti ártérfejlődés és a római kori Brigetio. Földrajzi Közlemények 137 (2013) 3. 278-286.

Prinz Gyula - Teleki Pál: Magyar földrajz. A magyar munka földrajza. Királyi Magyar Egyetemi Nyomda, Budapest 1937. 
Pyber Kálmán: Komárom keletkezésének és fejlödésének rövid összefoglaló ismertetése. Komáromi Nyomda, Komárom 1953.

Rédli Margit - Számadó Emese: Révkönyv: Komárom 2010. Komárom Város Önkormányzata, Komárom 2010.

Sikos T. Tamás - Tiner Tibor (szerk.): Egy város - két ország. Komárom - Komárno. Selye János Egyetem Kutatóintézete, Komárom 2007.

Simon Attila: A kettéosztott város. Az államhatár és az etnikumok közötti választóvonal által kettéosztott Komárom a két háború között. Fórum. Társadalomtudományi Szemle 13 (2011) 2. 87-100.

Sisa József - Dora Wiebenson: Magyarország épitészetének története. Vince Kiadó, Budapest 1998.

Štenpien, Erik: A megyerendszer Szlovákiában a XX. század első felében. Sectio Juridica et Politica 28 (2010) 103-110.

Szabady Béla: Győr szabad királyi város fejlődésének rövid története. Magyar Épitőmüvészet 42 (1943) 12. 276-281.

Számadó Emese: Új-Szőnytöl Komáromig. A komáromi ipar, iparosok, kereskedök és vendéglösök története (1896-1951). A komáromi Klapka György Múzeum Katalógusai VI. Komárom 2006.

Számadó Emese - Turi Zsolt (szerk.): A komáromi vasútvonalak története: 150 éves a déli vasút. A komáromi Klapka György Múzeum katalógusai, Komárom 2010.

Szénássy Árpád - Szénássy Zoltán: Komárom, a Duna Gibraltárja. KT Könyv- és Lapkiadó Kft., Komárom 2005.

Takáts Sándor: A dunai hajózás a XVI. és XVII. században. Magyar Gazdaságtörténelmi Szemle 7 (1900) 1-5. 97-122, 145-176, 193-222, 241-273, 288-319.

Takáts Sándor: Fejezetek Komárom müvelödés- és gazdaságtörténetéböl. Komárom-Esztergom Megyei Önkormányzat, Tatabánya 1996. 258-268.

Vizer János: Komárom 1800. Kéziratos térkép fényképmásolata. Megtalálható: BME Urbanisztikai Tanszék. Térképtár. K/72.

White, Richard: The Organic Machine: The Remaking of the Columbia River. Hill and Wang, New York 1995.

\title{
URBAN HISTORY OF THE DANUBE RIVERBANK OF KOMÁROM FROM THE BEGINNINGS TO 1945
}

\begin{abstract}
Summary
The study aims to show the connection between the historical town of Komárom/Komárno and the Danube riverside. The main structural feature of the town is the fortification function which formed the main accesses in the period of 1541-1686, when it represented a border fortification of the Habsburg Empire against the Ottomans. The former suburbs settlements opposite the Danube were destroyed in this period. In the 18th century, Komárom flourished as a market town of Danube axes, but its townscape, compared to its economic importance, has remained moderate. In the 19th century the fortress becomes again the dominant character. The main important points around the Danube occupy the strategic military installations. Only in the first decades of the 20th century will take place an approach of civil town to the Danube. It means an urban unification of historical Komárom and its suburb opposite the Danube (former Új-Szőny), too. A bridge was erected and shaped a representative place at bridgehead. Between the two world wars, the newly merged town parts were divided by a state border. The former common urban zones, first of all the bridge heads and the corso along the Danube were occupied by industrial facilities. Between the two Komároms an industrial puffer zone was developed, which is, still dominanting the structural feature of the town.
\end{abstract}

Keywords: town history, towns developing, Danube townscapes, divided twin towns, urban design, Gyula Wälder, Virgil Bierbauer 